Type of the Paper (Empirical paper)

\title{
Niche Theory Analysis of Sustainable Strategic Relationships among MICE Destinations: A Case of New Zealand
}

\author{
Jiwon Lee ${ }^{1 *}$
}

1 Hallym University;youninj77@gmail.com; jwlee04@hallym.ac.kr

* Correspondence: youninj77@gmail.com; Tel.: +82 1033179583 (South Korea)

\begin{abstract}
This study aimed to analyze the competitive relationship among meetings, incentive, convention and exhibition (MICE) destinations with reference to the notion of niche businesses in New Zealand; and to explore the existence of cooperative strategies between neighboring destinations. The data were collected from Ministry of Business, Innovation and Employment Reports on the Convention Activity Survey (CAS) in New Zealand. The study contributes towards an innovative and better understanding of the dynamics of sustainable destination competitiveness. It broadens the scope of MICE industry research by exploring new insights on the notion of destination competition and makes a theoretical connection between niche theory and the importance of coopetition. By investigating the case of MICE destinations of four northern central islands in New Zealand, this study provides information on the strategic significance of niche marketing for global destinations preparing for entrance into this market.
\end{abstract}

Keywords: Niche Theory; Sustainable MICE destination; Coexistence; Coopetition; Competitiveness

\section{Introduction}

The MICE (Meeting, Incentives, Convention, and Exhibitions) industry has grown significantly in recent years due to tourism being a major driving force of the global economy [1]. Awareness of this economic potential has led numerous local and national governments to devote resources to the development or expansion of MICE facilities [2]. However, the boom in MICE facilities development has not always produced positive result for local economies [3], and the evidence of destructive market forces in mature economies, characterized by increased competition and price deflation from overcapacity [4], should prompt policy analysts and let MICE sector managers reconsider their strategies. In the era of globalization, firms and organizations seek new opportunities in new markets and businesses for competitive advantage [5], and the competition for MICE business has shifted from competition amongst firms to competition amongst destinations [6]. In an ever more saturated market, the fundamental task for destination managers is to understand how this competition can be enhanced and sustained [7] resulting in a strong need to explore competitive advantage and to analyze actual competitive positions [8].

However, although the necessity for effective destination positioning strategies to make destination choice available to consumers has increased, and the recognition that an essential factor for the success of a destination is its ability to compete against other destinations by identifying and developing its competitive advantage [9], the few existing studies on MICE destination management have not yet been able fill the research gap for event management authorities on how to find their competitive niche position (market). They need to create desirable coexistence circumstances and develop a plan to reduce failure in competition. Current MICE destination competitiveness studies have been mainly focused on the criteria and/or attributes to satisfy the consumer from the demand-side [10-15]. They have also look at a destination's brand strategies for its attractiveness [16-17] by considering (re)visits, attracting business events as much as pos- 
sible, thus leading to fierce competition among destinations, but these are not integrated destination development strategies but short-term opportunistic strategies [18]. Thus, differentiated strategies should be developed by investigating what events are best for their destination, ones that best fit the existing infrastructure, markets and products, so that the destination is able to establish desirable competitive and co-existing circumstances by avoiding unsustainable competition.

Developing cooperation with other parties within a network is an important strategy to increase sustainable competitive advantage for any organization in a tourism destination [19]. Spatial proximity in a tourism destination drives businesses to develop cooperation by gaining shared resources and achieving common objectives [20]. Along with the growing awareness that competition and cooperation in business life can develop into a new co-evolution pattern [21], as well as service co-creation [22] and coopetition [23-24], especially in tourism destinations, competition is balanced with cooperation [25]. Since tourism destinations are typically comprised of numerous small businesses in spatial proximity that compete with one another, these firms also need to cooperate to attract visitors by combining their limited marketing resources and compete, in turn, with other destinations. Interestingly, the higher the level of complementarity there is between tourism services, the more firms will engage in collaboration in spite of being direct competitors [5]. According to inter-destination competitive dynamics, severe competition among destinations within a region weakens the overall effectiveness and efficiency of regional tourism development [20]. Having a neighboring destination with a competitive offer might not be a threat but may create opportunities for competitors [5]. Thus, it is important for destination management to understand who the potential cooperative partners may be [26].

In this vein, the present study addresses the following research objectives. First, it aims to analyze the competitive relationships in MICE destinations and to explore which advantageous position they should have with reference to the notion of niche theory, one of the effective ways to investigate the inter-competitive relationship within a single industry, as this theory supports co-existence according to the extent of competition among the organizations within a population. Secondly, this study aims to explore cooperative strategies between neighboring destinations by analyzing which destination has complementary resources since, based on the resource-based view of coopetition concept, the competitor who has similar or complementary resources could be a good partner [27]. Finally, this study presents theoretical contributions to extend the academic background in MICE research derived from adopting niche theory that has not yet been broadly applied to the MICE industry, and it also provides managerial implications on establishing marketing strategies for a MICE destination and stakeholders.

\section{Literature Review}

\subsection{Competitiveness in MICE Destination}

Competitiveness in the tourism literature as a crucial factor for the success of tourist destinations seems to imply that by being competitive a tourist destination could expand, and hence improve the quality of life of the populace [28]. Hong defines tourism competitiveness as the ability of a destination to create, integrate and deliver tourism experiences, including the value-added goods and services considered to be important by tourists [29]. These experiences sustain the resources of a destination and help it to maintain a sound market position relative to other destinations.

Studies on MICE destination's competitiveness are rare compared to the literature on tourism destinations, even though the underlying theoretical points are similar from a hospitality industry perspective [30]. One research trend is to examine the MICE site selection criteria where specific variables that influence the choice of criteria have been investigated. Crouch and Ritchie grouped 36 destination attributes into a set of eight primary categories: accessibility, local support, extra conference opportunity, accom- 
modation facilities, meeting facilities, information, site environment and others [31], which govern the choice of a convention site by other authors [10-11, 14-15, 32-34]. More recently, Jo, Park, Choe and Kim identified 24 important attributes affecting international association meeting destination selection by refining Crouch and Ritchies' model [1]. $\mathrm{Qu}$ and colleagues studied the competitiveness of Hong Kong as an international conference destination and concluded that accommodation, convention facilities, accessibility, safety and infrastructure systems were perceived as important site selection criteria [35]. Mahadewi, Bendesa and Antara investigated seven indicators - meeting facilities, hotels, accessibilities, entertainments, infrastructure, and airport facilities as latent exogenous variables of Bali as a MICE destination [17].

Another research trend is to examine the strengths and weaknesses of destinations to inform policymakers and industry partners of ways to use their strengths the best and to overcome their weaknesses towards the development of a successful MICE destination [36]. Sangpikul and Kim investigated the barriers impeding the success of Thailand's meeting and convention industry through qualitative interviews with industry stakeholders [37]. The barriers are the low quality of meeting and convention information, inadequate industry infrastructure, lack of professional or skilled staff, poor cooperation among industry partners, and political instability and security concerns. Yoo examined the attractiveness of South Korea as a convention destination via SWOT analysis and found strengths such as accessibility, geographic diversity, newly built convention facilities and advanced technology, and weakness such as rising hotel rates, shortages of skilled staff, low levels of proficiency in English, and negative media images [38].

Baloglu and Love examined the important attributes among five cities in U.S perceived by meeting planners and identified their strengths and weakness and the importance of perceptual dimensions in terms of marketing, positioning, and communication strategies [39]. On this, Nadkarni and Leong estimated the perception gap between critical attributes and performance for Macao as MICE venue via IPA analysis [40]. Also, McCartney studied the key perceptual development considerations for the convention and exhibition industry in Macao and his findings revealed that re-branding and infrastructure development were required to enhance the success and attractiveness of Macao as a MICE destination [13]. There are, however, some weaknesses in the above studies, such as the limitation of comparing only two cities [35], the focus on surveying mainly meeting planners or other stakeholders [39], and the descriptive analyses using case studies of each destination's infrastructure and/or competencies analysis [38]. Furthermore, most of these studies did not address the unique and distinctive set of competitiveness indicators of the various destinations, even though competitive advantage depends on the destination's ability to use these resources effectively over the long term. The only resources that were included were infrastructure investment, maintenance, growth and development, strategic planning and operational performance effectiveness and the like [29].

This study regards "MICE data" as the unique resource for MICE destination competitiveness. The aim of MICE destination marketing is to attract business events as frequently as possible to their venues, but at the same time, the most important issue is how to partition the available resources and plan business events among venues. Also, the specialization in a narrower range of tasks benefits the productivity and performance of a destination, as Akerman and Py suggested that a number of specific niche resource dimensions would inform competitiveness in the longer term [41]. Therefore, this study addresses the competitive relationship among destinations through the level and direction of competitiveness. This approach has not yet been explored in the literature, even though there is consensus that competitor actions have a direct impact on organizations or cities. Niche positioning and the concept of bio-ecological niches are useful lenses with which to examine this issue. 
The notion of a niche can be used to refer to the possibility of coexistence or extinction when two venues or destinations compete for the same resources in a defined environment [42]. The concept of a niche in this theory does not denote a proportion of the population. Rather, it describes a population's relationship to its environment [43]. In the sphere of biology and evolution, the term indicates how a population or individual responds to the distribution of resources and competitors in an ecosystem. The notion of a niche, which was developed originally from biology and evolution science, has been widely used in media studies to examine the competition among mass media outlets [44], and can be applied "in any situation in which clearly defined populations compete for limited resources" [45, p. 14]. Nelson and Winter have demonstrated that niche theory applies to trends in product competition [46] while McPherson extended the concepts of niche overlap in ecology to develop a method for measuring competition among non-profit organizations that are competing for members [47]. Kim and Park, in their turn, investigated competitive relationships among Korean public relation companies using niche theory [48]. Thus, this theory is useful for measuring competition among MICE destinations.

The niche in a resource domain is usually assessed using three conceptual measures: niche breadth, niche overlap and competitive superiority [49]. However, the present study only investigates niche overlap and niche breadth as two key concepts in the spatial model of niche activities and relates the niche to the environment and to the other populations in the community [50]. Comparative superiority weights competitive exclusion against displacement and better fulfills consumer gratification dimensions under competitive exclusion [51]. However this is not focused on in this research. Niche breadth entails the extent to which a destination satisfies a relatively broad or narrow spectrum of business event-related needs. It can be interpreted as relative specialism or in generalist terms. Specialists satisfy a relatively narrow set of needs and generalists satisfy a broader spectrum [52]. Niche overlap, or the extent to which media are perceived as similar, is indicated by the 'distance' between their dimension niches. Since the values of niche overlap measures denote the degree to which two destinations depend on the same resources, they serve as an indicator of the measure of competition among resources [50].

Since multifaceted resource dimensions such as advertising money, gratification utilities, consumer time and consumer spending in the media industry [44, 49] are important, the MICE industry entails several other resources pertaining to the environment of a destination such as infrastructure and economic or social ripple effects produced in the destinations by MICE activities. However, this study sets out to explore the volume of MICE events according to event type, customer type and delegate origin as multifaceted resource dimensions, since the volume of MICE events related to a venue are likely to be linked to the long-term survival of the destination due to their economic effects. Furthermore, the analysis of niche dimensions regarding event and/or customer types facilitates a better understanding of competitors' environments or characteristics. We explore how the four MICE destinations in Central Northern Island of New Zealand could both compete and complement each other for attracting the limited number of business events to these destinations. An ecological niche is defined as a place located in multidimensional space, such as a place to eat and time to eat [47]. Each of the populations in the business community aims to occupy a unique place in these multidimensional spaces, which means that a complex relationship among various types of interaction exists within an environment. Similarly, as MICE industry is convergent with complicated actors and stakeholders based on the industrial network with private and public sectors [3], each of the cities that wish to attract MICE events need to understand the unique niches of MICE sectors corresponding to their destination's environment and characteristics.

This study regards business event type, customer type and delegate origin as multidimensional niches for an analysis of the MICE sector's competitive relationship 
among destinations. Conference organizers and delegates are the key activators for site selection and are influenced by risks, the competitive environment, and overall economic, social and political trends and conditions, geographical distribution of the market (i.e. size, accessibility), the characteristics of the client or organization, its budgets and objectives, the evaluation of time-distance and cost-distance of the catchment area, the type of meeting, and so on [53]. On the other hand, exploration of the different types of customer, event type and delegate characteristics typically used by these destinations enables the destination's MICE environmental characteristics to be described. In light of this, the volume of business events with reference to customer type, event type and delegate has been adopted for niche analyses of the MICE industry.

\subsection{Coopetition and Niche Theory}

In management, marketing and tourism studies, competition and cooperation have recently been juxtaposed to the term 'coopetition' [23]. This term has been used by many researchers [54] who insist that organizations do not always engage in either competitive or cooperative relationships, but these often co-exist. Bengtsson and Kock suggest that a co-operative dyadic relationship is established when two competitors cooperate with each other in a strategic alliance for product development, while at the same time competing in the marketing of the resulting products [54]. Coopetition can be defined as cooperating to create a bigger business pie while competing to divide it up [24] and it is also defined as a strategic and dynamic process in which economic actors jointly create value through cooperative interaction, while they simultaneously compete to capture part of that value [55].

In neoclassical economic theory, people have rational preferences to maximize their utility through competition, but over time it has become evident that there are not only win-lose situations but also win-win and lose-lose situations that might be adopted by the players [5]. Fundamentally, as the notion of coopetition has two concepts: win-win strategy and lose-lose risk based on their extent of sharing resources and knowledge as advantages to be obtained from both competition and cooperation [56], the extent of the sharing of resources with competitors who have similar or complementary resources determines the success of the collaboration [27]. Organizations successfully completing paradoxical processes focus on their value creation regarding competitors as complementary and try to collaborate with their various resources and capabilities, thus, increasing the success-potential of coopetition [54]. The assumption is that many players may complement each other by avoiding mutual destructive strategic behaviors and achieving win-win conditions even if they are competitors.

By combining this viewpoint with rent seeking strategic behavior, the coopetition approach links with the competitive advantage objective since rent seeking refers to the search for the resources and capabilities necessary to obtain value-enhancing strategies to gain revenue above their opportunity cost [26]. The opportunity cost refers to the returns drawn from coopetition strategies over those of the best alternative, and the results depend on the use, allocation and exchange of resources [25]. Also, the major premise for coopetition between players is firstly to possess complementary resources and/or technologies [57], and secondly to have an optimal level of tension and competition between the players [58].

With the above reasoning, niche theory - which can explain competitive relationships, the level of competition (via niche overlap) and resource usage patterns (via niche breadth) among competitors - enables the understanding of the notion of a coopetition strategy, as niche overlap is considered as an index of the substitutability of complementarity of two players [59]. In other words, lower overlap reflects that two organizations are serving very different needs and that a greater sense of complementarity exists between them, meaning that they may adopt coopetition as a strategy. Similarly, Cho and Lee confirm through network analysis that both firms that serve a specialized market with low levels of competition and firms that are highly competitive with similar re- 
sources have low cooperative willingness [60]. Thus, the analysis of niche overlap and breadth enable an understanding of which destination pairs should adopt coopetition as a strategy.

In particular, the cooperative strategic suggestion is explored in the present study by focusing on the central region of the North Island of New Zealand - Hamilton, the Bay of Plenty, Rotorua and Taupo. While this tourism destination is considered as a business agglomeration and industrial district [61] the co-location, proximity and interconnectedness of local tourism companies of different sizes creates possibilities for businesses to cooperate while also competing [23]. Having a neighboring destination with a competitive offer might not necessarily be a threat but may also create opportunities even if too much competition among destinations within a region weakens the overall effectiveness of regional tourism development [20]. Also, geographic proximity, co-location and the consequent formation of micro clusters are sources of unintentional coopetition [26]. Destination Management Organizations (DMO) usually favors both intentional and unintentional cooperative connections, thus creating more versatile strategic options.

With above reasoning the research questions are firstly to explore niche breadth and overlap among four MICE destination by type of event, customer and delegate origin and secondly to explore which destination pairs within four regions are better suited to adopt coopetition strategy their competitive advantage and sustainability.

\section{Methodology}

\subsection{Sample and Data Collection}

The sample for this research was collected from the Ministry of Business, Innovation and Employment reports for the Convention Activity Survey (CAS), which measures business event activity at qualifying venues in New Zealand from 2011 to 2018. The qualified venues included in CAS are classified into five types: event or convention centers, stadium/showgrounds, hotels, other forms of accommodation (such as motels, motor lodges and the like), and other venues (including restaurants, vineyards, and theaters). These participants had to promote their venues as suitable for a range of business-related activities, especially conventions/conferences and meetings; they had to have a theater-style venue with minimum capacity of 50 people and aim or plan to host a minimum of 12 conventions and/or business-related events each year.

Event are also classified into five types: meeting/seminar, (that is a formal gathering of people to discuss matters of shared of interest usually within a single session); incentive activities defined as activities that incentivize or reward the invited event delegates for exceptional business achievement; conference/convention (formal gathering of people to discuss shared interests involving multiple sessions and speakers); trade shows/exhibition (showcases of goods and services held for the benefits of a specific industry); and special occasion activities which are social gatherings or celebrations such as gala diners, balls, graduation ceremonies, cocktail parties, birthday parties or weddings. The customer types are classified into associations, business, government, education, personal and others; while delegate origins are classified into local, regional, international, or Australian.

\subsection{Analysis of Niche Dimension}

As discussed above, niche breadth refers to the variety of categories within a resource domain consumed/exchanged through the MICE destinations. In this study, the resource dimensions are the types of customer, type of event and delegate. According to Dimmick, Patterson and Albarran research theory [45], the niche breadth formula can be calculated as figure 1(a).

Pi represents the proportion of total volume of MICE events in each resource category i (e.g. meeting/seminar, incentive activities, conference/convention, 
tradeshow/exhibition, special occasions) used by population A (such as Auckland or Hamilton). Three resource dimensions are calculated with this formula. Lower values of $B$ indicate that business event types are concentrated in fewer categories. Niche overlap is a measure of how similar two destinations are with regard to the holding of MICE event resources they attract and generally regarded as an index of ecological similarity which can often be interpreted as indicating competition between two populations. The niche overlap for two populations can be calculated as figure 1(b).

$$
B=\frac{1}{\sum_{i=1}^{m} P i^{2}}
$$

(a)

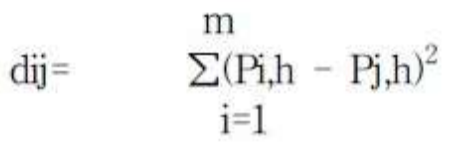

(b)

Figure 1. Niche Theory formula. (a): niche breadth, (b): niche overlap

Where: the term dij denotes the distance between destinations $i$ and $j, h$ represents the resource categories by event type, customer type and delegate origin; $\mathrm{Pi}, \mathrm{h}$ is the proportion of destination j's total volume of MICE events in each resource category and $\mathrm{Pj}, \mathrm{h}$ is the proportion of destination j's total volume of MICE events in each resource category, and $\mathrm{m}$ is the mean value. If the geometric distance is equal to a value of zero, there is perfect overlap or perfect similarity in resource use. Values that are higher than zero denote less overlap or ecological similarity in resource use [50]. Based on the above formula Figure 1 shows the calculation model of the niche breadth and overlap.

\section{Results}

Analyzing the New Zealand Convention Activity Survey reports from 2011 to 2018 shows that the total volume of all business events held in New Zealand was 363,245 $(45,445$ on average per year). More than $32 \%$ of these were in Auckland, around $16 \%$ in were Wellington during the entire period, while the Christchurch and Hamilton regions collectively shared third place. Meetings/seminars displayed the highest volume by event type: almost more than $60 \%$, and special occasion events ranked next with about $20 \%$ in average all over the regions, but the ratios differ between regions. Business events (about 50\%) reached first rank and association events (about 12\%) second in total volume by customer type averaged over the regions. Almost $30 \%$ of these were held in Auckland, while approximately $15-17 \%$ was held in Wellington. The total number of delegates was 26.2 million and averaged 3.2 million throughout the eight years (2011 to 2018) at all business events in New Zealand. Over 95\% were domestic and local delegates and an average $36 \%$ of the total volumes of delegates were in Auckland. Around $17 \%$ took place in Wellington (second place) and Christchurch and Hamilton (9\% on average) were in third place throughout the whole year. However, Queenstown was in second rank for international delegates, followed by Auckland (refer to Appendix A-C). If Hamilton where currently positioned forth destination in terms of the volume has cooperative strategy with central regions of islands; Taupo, Rotoru and Bay of Plenty, they would come up to the second stage followed by Auckland in NZ.

Table 1. Total volumes of event data for eight years (2011-2018)

\begin{tabular}{ccccc}
\hline \multirow{2}{*}{ Regions } & \multicolumn{2}{c}{ Total N. of events } & \multicolumn{2}{c}{ Total N. of delegates } \\
\cline { 2 - 5 } & Total number & $\mathbf{M}(\%)$ & Total number & $\mathbf{M}(\%)$ \\
\hline AUC & 114.528 & $14.320(32)$ & $9,532,317$ & $1,191,540(36)$ \\
BOP & 16,621 & $2,078(5)$ & $1,128,679$ & $141,085(4)$ \\
C\&C & 35,594 & $4,449(10)$ & $2,335,567$ & $291,946(9)$ \\
DUN & 11,582 & $1,448(3)$ & 764,795 & $95,599(3)$ \\
HAM & 34,864 & $4,358(10)$ & $2,235,532$ & $279,441(9)$ \\
\hline
\end{tabular}




\begin{tabular}{ccccc}
\hline HAWK & 11,334 & $1,417(3)$ & 661,998 & $82,750(3)$ \\
MANA & 27,896 & $3,487(8)$ & $2,031,462$ & $253,933(8)$ \\
MARL & 5,461 & $683(2)$ & 310,455 & $38,807(1)$ \\
NELS & 12,021 & $1,503(3)$ & 695,972 & $86,996(3)$ \\
QUEEN & 9,997 & $1,250(3)$ & 570,218 & $71,277(2)$ \\
ROT & 15,214 & $1,902(4)$ & 999,455 & $124,932(4)$ \\
TAU & 9,451 & $1,181(3)$ & 374,872 & $46,859(1)$ \\
WELL & 58,651 & $7,331(16)$ & $4,571,867$ & $571,483(17)$ \\
Total & $\mathbf{3 6 3 , 2 4 5}$ & $\mathbf{4 5 , 4 4 5 ( 1 0 0 )}$ & $\mathbf{2 6 , 2 1 3 , 1 8 8}$ & $\mathbf{3 , 2 7 6 , 6 4 9 ( 1 0 0 )}$ \\
\hline
\end{tabular}

AUC: Auckland, BOP: Bay of Plenty, C\&C: Christchurch and Canterbury, DUN: Dunedin, HAM: Hamilton, HAWK: Hawkes Bay, MANA: Manawatu, MARL: Marlborough, NEL: Nelson, QUEEN: Queenstown, ROT: Rotorua, TAU: Taupo, WELL: Wellington.

Niche breadth and overlap analysis have been analyzed by focusing on the central region of the North Island of New Zealand - Hamilton, the Bay of Plenty, Rotorua and Taupo. The niche breadth values among the four MICE destinations on the event type resource dimension are reported in Tables 2 and 3. Examining the means of the niche breadth values throughout the entire period, the Hamilton $(\mathrm{M}=1.896)$ region appeared to be a relative specialist in this domain by focusing on 'Meeting/Seminar' category during the whole period except in 2011 and 2018. Rotorua became more generalist during recent year from 2015 to 2017, being on averagely generalist $(M=2.615)$ throughout the year by broadening their market to social occasion events (see Appx A). Totally, Hamilton seeks a specific niche strategy in the meeting/seminar category and Rotorua and Taupo are relatively generalists who have broad niches in event type dimension.

In terms of niche overlap pertaining to the event type resources reported in Table 3, Bay of Plenty (BOP)/Hamilton (0.008) pair has the highest competitive value with similar resources such as meeting/seminar and special events. In contrast, Hamilton/Rotorua (0.052) showed the lowest competition and Hamilton/Taupo (0.043) followed, suggesting that these regions are using different types of events and pointing to the possibility for this grouping to complement their resources. In other words, Hamilton and BOP has a similar use pattern for event type, on the other hand Rotorua and Taupo are more focused on the conference dimension rather than the meeting/seminar dimension, both are competitive with each other but have low competition with Hamilton. Thus, Taupo and Rotorua would be better off if they were to cooperate with Hamilton for competitive advantage by supporting each other to host events - meetings/seminars for Hamilton, conferences in Taupo and special social events in the Bay of Plenty and Rotorua. Having specialized niches might reduce the level of competition and make them complement each other on the event type resource dimension.

Table 2. Niche Breadth by the resources dimensions

\begin{tabular}{|c|c|c|c|c|c|c|c|c|c|c|}
\hline Div. & Reg. & 2011 & 2012 & 2013 & 2014 & 2015 & 2016 & 2017 & 2018 & Mean \\
\hline \multirow{4}{*}{$\underset{\text { 岌 }}{\overrightarrow{0}}$} & BOP & 2.691 & 2.273 & 2.136 & 2.196 & 2.062 & 1.984 & 1.994 & 2.111 & 2.181 \\
\hline & HAM & 2.107 & 1.995 & 1.939 & 1.868 & 1.817 & 1.856 & $1.757^{*}$ & 1.826 & $1.896^{*}$ \\
\hline & ROT & 2.814 & 2.399 & 2.380 & 2.567 & 2.653 & $2.832^{* *}$ & 2.533 & 2.740 & $2.615^{* *}$ \\
\hline & TAU & 2.751 & 2.619 & 2.340 & 2.778 & 2.438 & 2.547 & 2.245 & 2.722 & 2.555 \\
\hline \multirow{4}{*}{ 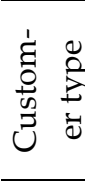 } & BOP & 3.481 & 3.449 & 3.841 & 4.506 & $4.554^{* *}$ & 4.155 & 3.492 & 3.148 & 3.828 \\
\hline & HAM & 2.640 & 3.036 & 3.084 & 3.762 & 3.673 & 3.340 & 2.991 & 2.910 & 3.179 \\
\hline & ROT & 2.826 & 2.984 & 3.797 & 3.995 & 3.812 & 4.554 & $4.635^{* *}$ & 4.187 & $3.849^{* *}$ \\
\hline & TAU & 2.650 & 3.100 & 3.092 & 4.036 & 3.916 & 4.064 & 3.241 & 3.634 & 3.467 \\
\hline \multirow{3}{*}{ 夢 } & BOP & 1.650 & 1.481 & 1.649 & 1.673 & 1.580 & 1.662 & 1.602 & 1.436 & 1.592 \\
\hline & HAM & $1.408^{*}$ & 1.446 & 1.548 & 1.457 & 1.502 & 1.543 & 1.493 & 1.470 & $1.483^{*}$ \\
\hline & ROT & 2.325 & 2.185 & $2.405^{* *}$ & 2.300 & 2.294 & 2.409 & 2.290 & 2.340 & $2.318^{* *}$ \\
\hline
\end{tabular}




\begin{tabular}{rrrrrrrrrr}
\hline TAU & 2.278 & 2.151 & 2.050 & 2.069 & 2.140 & 2.321 & 2.154 & 2.074 & 2.154 \\
\hline${ }^{*}$ Specialists, ${ }^{* *}$ Generalists & & &
\end{tabular}

Table 3. Niche Overlap by event type

\begin{tabular}{ccccccc}
\hline Yr. & BOP/HAM & BOP/ROT & BOP/TAU & HAM/ROT & HAM/TAU & ROT/TAU \\
\hline 2011 & 0.020 & 0.028 & 0.008 & 0.035 & 0.020 & 0.006 \\
2012 & 0.007 & 0.010 & 0.012 & 0.016 & 0.029 & 0.005 \\
2013 & 0.005 & 0.012 & 0.018 & 0.017 & 0.023 & $\mathbf{0 . 0 0 1}^{*}$ \\
2014 & 0.011 & 0.022 & 0.082 & 0.043 & $\mathbf{0 . 1 0 4}^{* *}$ & 0.021 \\
2015 & 0.010 & 0.034 & 0.033 & 0.049 & 0.043 & 0.002 \\
2016 & 0.002 & 0.068 & 0.024 & 0.093 & 0.036 & 0.019 \\
2017 & 0.006 & 0.033 & 0.005 & 0.065 & 0.020 & 0.018 \\
2018 & 0.003 & 0.058 & 0.033 & 0.098 & 0.068 & 0.024 \\
$\mathbf{M}$ & $\mathbf{0 . 0 0 8}^{*}$ & $\mathbf{0 . 0 3 3}$ & $\mathbf{0 . 0 2 7}$ & $\mathbf{0 . 0 5 2}$ & $\mathbf{0 . 0 4 3}$ & $\mathbf{0 . 0 1 2}$ \\
\hline
\end{tabular}

${ }^{*}$ High competition, ${ }^{* *}$ Low competition

Tables 2 and 4 showed the pattern of niche breadth and niche overlap among the four MICE destinations over the total volume of MICE events by five different customer types. Niche breadth values indicate that all the regions are mostly generalized, ranging from 3.179 to 3.849 on average values which is larger than the median, 2.5, throughout the entire period (see Table 2). The total impact of business customers is relatively high, but the Rotorua regions included other customer types and are increasingly hosting fewer business events and seeking to be generalists (see Appx.B).

The values of niche overlap for MICE events by customer type indicate that almost pairs of regions demonstrated high levels of competition reaching overlap values from averagely 0.009 to 0.021 by focusing on strongly association and business customers (see Appx.B). The Bay of Plenty/Taupo $(\mathrm{M}=0.017)$ and Hamilton/Rotorua $(\mathrm{M}=0.021)$ pairs showed relatively lower levels of competition. Especially, the Bay of Plenty and Hamilton regions are similarly positioned, highly competitive, within the personal and other event customer sectors. Therefore, coopetition between Rotorua and Hamilton while supporting education in Hamilton and the personal and other sector in Rotorua with a co-marketing strategy would be better for their mutual growth in the total number of events held.

Table 4. Niche Overlap by customer type

\begin{tabular}{ccccccc}
\hline Yr. & BOP/HAM & BOP/ROT & BOP/TAU & HAM/ROT & HAM/TAU & ROT/TAU \\
\hline 2011 & 0.024 & 0.013 & 0.021 & 0.002 & 0.008 & 0.008 \\
2012 & 0.006 & 0.006 & 0.007 & $\mathbf{0 . 0 0 0 ^ { * }}$ & 0.009 & 0.009 \\
2013 & 0.010 & 0.006 & 0.019 & 0.020 & 0.016 & 0.016 \\
2014 & 0.007 & 0.007 & 0.038 & 0.003 & 0.037 & 0.037 \\
2015 & 0.011 & 0.012 & 0.018 & 0.004 & 0.017 & 0.017 \\
2016 & 0.008 & 0.021 & 0.010 & 0.042 & 0.016 & 0.016 \\
2017 & 0.004 & 0.043 & 0.007 & $\mathbf{0 . 0 6 4}$ & 0.009 & 0.009 \\
2018 & 0.002 & 0.028 & 0.013 & 0.034 & 0.018 & 0.018 \\
$\mathbf{M}$ & $\mathbf{0 . 0 0 9}^{*}$ & $\mathbf{0 . 0 1 7}$ & $\mathbf{0 . 0 1 7}$ & $\mathbf{0 . 0 2 1}^{* *}$ & $\mathbf{0 . 0 1 6}$ & $\mathbf{0 . 0 1 6}$ \\
\hline
\end{tabular}

${ }^{*}$ High competition, ${ }^{* *}$ Low competition

Tables 2 and 5 indicate the distribution patterns of the total volume of MICE events by delegate origin in terms of niche breadth and niche overlap for the four MICE destinations. Rotorua and Taupo regions were the mostly generalists with having each 2.315, 2.154, while Hamilton and BOP were the relatively high degree of specialization with each value of 1.483 and 1.592 . The overlap value of the delegate origin dimension indi- 
cates that the Bay of Plenty/Hamilton pair has comparatively high competition levels with a value of 0.004 since they are competing for similar local and domestic delegates (see Appx. C). On the other hand, Hamilton/Taupo $(\mathrm{M}=0.210)$ showed the lowest competition, followed by the Bay of Plenty/Taupo $(\mathrm{M}=0.177)$, meaning that these destinations focus on different delegate origin dimensions. This suggests a sound possibility for complementarity in terms of their resources. However, since the Taupo region has comparatively high competitiveness in this dimension with reference to all of NZ, their intention to strategically cooperate with other regions for sharing delegates is likely to be low. Rather, coopetition between Hamilton and Rotorua would be more realistic as both demonstrate modest levels of overlap $(\mathrm{M}=0.122)$ in the delegate origin dimension.

Table 5. Niche Overlap by delegate origin

\begin{tabular}{ccccccc}
\hline Yr. & BOP/HAM & BOP/ROT & BOP/TAU & HAM/ROT & HAM/TAU & ROT/TAU \\
\hline 2011 & 0.009 & 0.105 & 0.155 & 0.175 & 0.237 & 0.005 \\
2012 & $\mathbf{0 . 0 0 0}^{*}$ & 0.084 & 0.218 & 0.091 & 0.228 & 0.035 \\
2013 & 0.002 & 0.071 & 0.328 & 0.094 & $\mathbf{0 . 3 7 6}$ & 0.106 \\
2014 & 0.012 & 0.071 & 0.328 & 0.094 & $\mathbf{0 . 3 7 6}$ & 0.106 \\
2015 & 0.001 & 0.104 & 0.111 & 0.124 & 0.132 & 0.002 \\
2016 & 0.003 & 0.119 & 0.107 & 0.161 & 0.146 & 0.001 \\
2017 & 0.002 & 0.093 & 0.075 & 0.124 & 0.103 & 0.002 \\
2018 & $\mathbf{0 . 0 0 0}^{*}$ & 0.129 & 0.094 & 0.117 & 0.083 & 0.005 \\
M & $\mathbf{0 . 0 0 4}^{*}$ & $\mathbf{0 . 0 9 7}$ & $\mathbf{0 . 1 7 7}$ & $\mathbf{0 . 1 2 2}$ & $\mathbf{0 . 2 1 0}$ & $\mathbf{0 . 0 3 3}$ \\
\hline
\end{tabular}

${ }^{*}$ High competition, ${ }^{* *}$ Low competition

\section{Discussion}

With the lucrative MICE industry having economic and social impacts on the host region, the issues of global competition in this sector have been shifted to inter-regional management beyond cross boarder competition, finding an appropriate comparative position avoiding a fierce market would be a long-term sustainable survival strategy in destination management. The result of this study provides a fine-grained analysis of the relationships that extend beyond competitive contexts. Niche theory is capable of dealing with such complexity and offers a fine-grained set of techniques for strategic alternatives that overcome the limitations of other studies. Our key findings outline the significance of niche breadth and then niche overlap measures of competition for resources on multiple dimensions for a population of organizations in an economic sector, within a bounded region influenced by common political, social and economic environmental conditions. By applying niche theory, which has rarely been discussed in destination management, to explain the comparative relationship among the four northern central region's' MICE destinations in New Zealand, this study provides a few important results and contributes to the understanding of MICE tourism in the regions that can be applied to other destinations worldwide.

First, it demonstrated that four regions generally share similar resources in event type, customer type and delegate origin dimension, as all are mainly focused on meeting/seminar, business event and local delegate attraction resulting comparatively high competition between especially Hamilton/BOP (Bay of Plenty). Meanwhile, Hamilton/Rotorua or Taupo showed relatively low competition in terms of event type as Rotorua and Taupo have focused on conference and convention avoiding high occupation of meeting/seminar. Low overlap and relatively specialist strategy is suit for the most appropriate competitiveness. In this sense, Hamilton as specialist is required to cooperative strategy with Rotorua or Taupo by reducing the competition with Bay of Plenty, in result they would be the region to have competitive advantage in central area in NZ.

Second, the relative extent of the competitive relationship between pair regions differs by year according to their resource usage pattern but this study demonstrated that 
the level of competition is reduced when they alter their niche dimension by escaping from concentration on resources. As the research shows, Rotorua has had a low level of competition with other regions on average since 2015 due to being more attractive for special social events. Meanwhile, Bay of Plenty failed to avoid a fierce competitive situation since they focused too much on concentrated resources like meetings/seminars and business customers, which are mostly shared by others. This result supports the argument that the way to sustain competitiveness is to find the actual competitive position, and if each region is selective and differentiate their markets vis-a-vis each other to identify their competitive position and environmental conditions, then they might avoid high levels of competition [8].

Third, at higher densities, competition is stronger, there is higher mortality, reduced funding rates may occur, and possible extinction should be anticipated if policy and strategic planning do not curb growth. Hence, it is essential that inter-organizational collaboration occurs in research activities, defining shared goals, and measuring impacts [62]. The case in point is Hamilton that has been able to survive in the strong competition from other regions by concentrating on meetings/seminars within the education field by cooperating with Rotorua which gives them low competition. Instead Hamilton would better to abandon the social occasion and conference sector. Also, the Bay of Plenty should try to cooperate with Taupo while concentrating on conferences for Taupo and social events for the Bay of Plenty. Thus, this study revealed that Hamilton vs. Rotorua, and Bay of Plenty vs. Taupo are better suited to the adoption of a coopetition strategy using niche overlap as an index of complementarity for the two players.

In summary, competitive and co-existent relationships were identified using niche theory focused on micro-dimensional niche characteristics such as type of customer, event type and delegate origin. Coexistence depends on the factors of customer characteristics and volume of the customer segments, and competition depends on the level of the common resources that they have control over. Thus, this study has given a more nuanced view of the situation when destinations compete; they are affected by the total volume of MICE events, but coexistence depends on customer and event type. These results have implications for the future of the MICE industry and its long-term viability.

\section{Conclusion}

\subsection{Theoretica Contribution}

As competition continues to grow with the current trend of globalization, establishing an appropriate position with a competitive advantage and a sound understanding of working relationships among destinations is very important for collaborative destination marketing [25]. This study contributes to the business events literature by exploring how each MICE destination in New Zealand occupies a competitive position in their respective niche markets. This is done by analyzing multi-dimensional resources using patterns. The study also offers suggestions as to how regions can develop cooperative strategic partners among neighboring competitors, especially in the central North Island. Our analysis contributes towards the scholarly literature in the field in a number of ways.

First, it contributes towards a better understanding of the dynamics of destination competitiveness and broadens the scope of MICE industry research by applying mass media communication theories to business communication to explain the competition and coexistence of MICE destination relationships. This contribution can form a foundation from which to expand the application of these theoretical concepts to the hospitality and tourism industry. For example, the hotel industry also competes for the limited resources such as business and/or leisure tourists, accommodation price, location, etc. To evade competition and to find a strategic niche, they need to know their competitors, identify their niche position and explore alternatives to competition. Hence, this study suggests an adaptation of niche theory beyond the MICE industry. Furthermore, by ap- 
plying readily available secondary data that has not been used before in this manner, this study identified new resource dimensions with which to examine the competitive relationships in MICE destinations that transcend the limited measures of destination attributes and selection criteria used in previous studies based on customer perceptions.

Secondly, this study explores the competitive relationships between local destinations within a nation, rather than the commonly addressed international competition. The top-tier city in the MICE industry may be focused on international competition, but the second or third-tier cities are mostly interested in competing with local opponents for internal markets. Thus, this study may give rise to a number of significant benefits for second-tier destinations in terms of how to find niche positions for long-term survival and coexistence.

Thirdly, it extends niche theory by developing a new term, the notion of a strategic niche and a way of visualizing niche breadth that has not been discussed in the prior research that has mainly focused on uni-dimensional comparisons of destinations, features and/or services based on the absolute evaluation of a specific criteria, or the economic impacts that have not addressed organic relationships, both of which this study has achieved. Future research could look at such environmental variations to establish their impact.

Lastly, this study pioneers the significant theoretical notion that niche theory, which has been applied to competitive relationships, could explain coopetition, even though it only focuses on the case of the central North Island of New Zealand. Also, it presents a new approach towards coopetition using niche overlap value together with niche theory, and links both conceptually since most coopetition research in the tourism and hospitality literature tends to opt for conceptualization, literature review and qualitative approaches, with mostly single or multiple case studies [55].

\subsection{Managerial Implications}

Along with the above theoretical implications, the findings of this study provide several practical insights into destination management in applying the industry context.

Firstly, most regions in New Zealand lies in the high competition in the business event market as indicated - the average niche overlap ranged from 0.01 to 0.07 with reference to event type and customer type dimensions. Although there is a very high degree of overlap between them regarding the resource dimensions under analysis, the different consumer usage patterns found in this study (differences in niche) allow four MICE destinations currently to coexist. For example, the Hamilton region is competitively positioned with a narrow niche breadth and low niche overlap with Rotorua and Taupo in terms of event dimensions, especially regarding specializing in meetings/seminars.

Secondly, this study suggests that the destinations should find appropriate niche dimensions necessary for sustainable strategic survival in the fierce competition of the MICE industry. For example, Taupo needs to attract more conferences amongst different business event categories to bypass the strong competition in the event type dimension. Similarly, Hamilton and Rotorua /Bay of Plenty would be better to focus on education customer business events and social occasions respectively.

Thirdly, with the premise of a consistent growth in global MICE events, this result would have strategic significance in the niche marketing for a destination preparing for new entrance to understand the potential niche market that they should position themselves for. Also, for the government policymaker, the guideline of competition policy to assist regions to move to using less concentrated resources could be achieved by devoting their political support to this position. This would result in better opportunities for resources to be allocated to meet the needs of the regions for co-existence under a competitive environment. 
In addition, although this study investigated competition and coexistence among only four MICE destinations, it suggests that some of the destinations require strategic cooperation to gain from the powerful competitiveness within close range of each other. Some researchers indicate that organizations do not always need to engage in either competitive or cooperative relationships with others but can co-exist in fruitful ways. The term coopetition is simultaneous cooperation and competition and both relationships are dependent on the closeness of their activities to the customer.

\subsection{Limitations and Further Research}

This study did not address deeper concerns since its aim was to mainly analyze business event data provided by Conventions \& Incentives New Zealand (CINZ). If more detailed information about delegate characteristics can be obtained, the strategic positioning between Taupo and Rotorua could be further developed. Thus, future research requires investigating more resource motivation dimensions such as user gratification, infrastructure, or event theme. Second, the issue of the generalizability of the competitive relationship remains due to limited case applications such as event type, customer and delegate origin dimensions, even though the present study provides a new theoretical insights and measurement tool by exploring competition intensity via niche overlaps in the coopetition literature of hospitality management. Limiting measures to a few resource dimensions and snapshots of four regions over eight years also restricts the in-depth nature of the study findings, but the overall trends are seen to persist, and the investigation helps us understand a theoretical concept and the nature of the relationship between the constructs. Accordingly, this issue should be extended to other various resource domains to verify the generalizability of the results. Lastly, the current study did not address how we might develop substantial strategic coopetition relationships, but merely indicates the ideal relations for coopetition. Yet, the significance to add one ray to the deficient quantitative research will make some motivation to the further research.

Author Contributions: Conceptualization, All; methodology and analysis, J. L; Writing; J. L; Review and editing; E. Y. All authors have read and agree to the published version of manuscript.

Funding: This research received no external funding.

Conflicts of Interest: The authors declare no conflict of interest.

Appendix A. Total volume by event type dimension for eight years (2011-2018)

\begin{tabular}{lccccccc}
\hline Region & M.S(\%) & Incent.(\%) & C\&C(\%) & Ex.(\%) & Special(\%) & N.A(\%) & Total \\
\hline AUC & $67,792(59)$ & $1,384(1)$ & $13,474(12)$ & $1,927(2)$ & $20,094(18)$ & $858(1)$ & 114,558 \\
BOP & $10,492(63)$ & $315(2)$ & $1,516(9)$ & $357(2))$ & $3,870(23)$ & $72(0)$ & 16,621 \\
C\&C & $24,416(69)$ & $848(2)$ & $3,102(9)$ & $639(2)$ & $6,373(18)$ & $216(1)$ & 35,594 \\
DUN & $7,469(64)$ & $278(2)$ & $1,157(10)$ & $317(3)$ & $2,280(20)$ & $82(1)$ & 11,582 \\
HAM & $24,446(70)$ & $640(2)$ & $2,713(8)$ & $587(2)$ & $3,670(18)$ & $108(0)$ & 34,864 \\
HAWK & $7,036(62)$ & $225(2)$ & $862(8)$ & $248(2)$ & $2,885(25)$ & $78(1)$ & 11,334 \\
MANA & $18,575(69)$ & $479(2)$ & $2,493(9)$ & $519(2)$ & $5,618(20)$ & $212(1)$ & 27,896 \\
MARL & $2,605(60)$ & $149(3)$ & $426(10)$ & $103(2)$ & $1,017(24)$ & $6(0)$ & 4,308 \\
NELS & $7,364(61)$ & $454(4)$ & $1,039(9)$ & $292(2)$ & $2,741(23)$ & $132(1)$ & 12,021 \\
QUEEN & $5,315(53)$ & $669(7)$ & $1,816(18)$ & $253(3)$ & $1,850(19)$ & $94(1)$ & 9,997 \\
ROT & $7,131(47)$ & $357(2)$ & $2,549(17)$ & $282(2)$ & $3,830(25)$ & $123(1)$ & 15,214 \\
TAU & $5,230(55)$ & $200(2)$ & $1,848(20)$ & $116(1)$ & $2,000(21)$ & $56(1)$ & 9,451 \\
WELL & $37,077(63)$ & $987(2)$ & $9,069(15)$ & $1,019(2)$ & $10,082(17)$ & $417(1)$ & 58,652 \\
\hline
\end{tabular}

M.S: meeting/seminar, Incent.; Incentive Activity, C\&C: conference \& convention, Ex: exhibition, trade show, N.A: not-acknowledged 
Appendix B. Total volume by customer type dimension for eight years (2011-2018)

\begin{tabular}{|c|c|c|c|c|c|c|c|c|}
\hline Region & Ass.(\%) & $\operatorname{Biz}(\%)$ & Govern. (\%) & Edu. (\%) & Pers. (\%) & Others(\%) & N.A(\%) & Total( $(\%)$ \\
\hline \multirow{2}{*}{ AUC } & 16,147 & 64,077 & 11,234 & 9,081 & 7,583 & 2,646 & 3,767 & 114,534 \\
\hline & $(14)$ & $(56)$ & $(10)$ & $(8)$ & $(7)$ & $(2)$ & (3) & $(100)$ \\
\hline \multirow{2}{*}{ BOP } & 2,633 & 7,382 & 1,848 & 1,672 & 2,040 & 569 & 546 & 16,691 \\
\hline & $(16)$ & $(44)$ & $(11)$ & $(10)$ & $(12)$ & (3) & (3) & $(100)$ \\
\hline \multirow{2}{*}{$C \& C$} & 5,345 & 20,507 & 3,034 & 2,482 & 3,281 & 513 & 614 & 35,775 \\
\hline & $(15)$ & $(57)$ & $(8)$ & $(7)$ & (9) & (1) & $(2)$ & $(100)$ \\
\hline \multirow{2}{*}{ DUN } & 1,938 & 5,122 & 1,283 & 1,555 & 970 & 320 & 410 & 11,597 \\
\hline & $(17)$ & $(44)$ & $(11)$ & (13) & (8) & (3) & $(4)$ & $(100)$ \\
\hline \multirow{2}{*}{ HAM } & 4,788 & 17,898 & 3,431 & 3,343 & 3,161 & 1,036 & 1,140 & 34,797 \\
\hline & $(14)$ & $(51)$ & $(10)$ & $(10)$ & $(9)$ & (3) & (3) & $(100)$ \\
\hline \multirow{2}{*}{ HAWK } & 1,454 & 5,264 & 1,178 & 1,094 & 1,547 & 467 & 302 & 11,306 \\
\hline & (13) & $(47)$ & $(10)$ & $(10)$ & $(14)$ & $(4)$ & (3) & $(100)$ \\
\hline \multirow{2}{*}{ MANA } & 4,157 & 13,595 & 2,928 & 2,866 & 2,708 & 728 & 765 & 27,746 \\
\hline & $(15)$ & $(49)$ & $(11)$ & $(10)$ & $(10)$ & (3) & (3) & $(100)$ \\
\hline \multirow{2}{*}{ MARL } & 809 & 2,425 & 504 & 394 & 552 & 314 & 118 & 5,116 \\
\hline & (16) & $(47)$ & (10) & (8) & (11) & (6) & (2) & $(100)$ \\
\hline \multirow{2}{*}{ NELS } & 2,349 & 5,023 & 1,137 & 1,275 & 1,658 & 202 & 363 & 12,007 \\
\hline & $(20)$ & $(42)$ & (9) & $(11)$ & (14) & $(2)$ & (3) & $(100)$ \\
\hline \multirow{2}{*}{ QUEEN } & 1,457 & 5,757 & 647 & 660 & 902 & 186 & 453 & 10,062 \\
\hline & $(14)$ & $(57)$ & $(6)$ & (7) & (9) & $(2)$ & (5) & $(100)$ \\
\hline \multirow{2}{*}{ ROT } & 2,417 & 5,843 & 1,049 & 962 & 1,778 & 966 & 486 & 13,501 \\
\hline & (18) & $(43)$ & $(8)$ & (7) & (13) & $(7)$ & $(4)$ & $(100)$ \\
\hline \multirow{2}{*}{ TAU } & 1,610 & 4,503 & 627 & 431 & 1,295 & 340 & 633 & 9,439 \\
\hline & $(17)$ & $(48)$ & $(7)$ & (5) & $(14)$ & $(4)$ & $(7)$ & $(100)$ \\
\hline \multirow{2}{*}{ WELL } & 9,004 & 23,109 & 9,857 & 4,733 & 2,994 & 1,400 & 1,059 & 52,155 \\
\hline & (17) & $(44)$ & (19) & (9) & (6) & (3) & $(2)$ & $(100)$ \\
\hline
\end{tabular}

Ass.: Association, Biz: Business, Govern.: Government, Edu.: Education, Pers.: Personal, N.A: not-acknowledged. Blanks are ratio.

Appendix C. Total volume by delegate origin dimension for eight years (2011-2018)

\begin{tabular}{cccccc}
\hline Region & Local(\%) & Domestic(\%) & Australian(\%) & Int'l(\%) & Total(\%) \\
\hline AUC & $5,468,874(80)$ & $1,131,096(16)$ & $118,941(2)$ & $155,609(2)$ & $6,874,520(100)$ \\
BOP & $793,445(77)$ & $217,810(21)$ & $10,025(1)$ & $15,763(2)$ & $1,037,043(100)$ \\
C\&C & $1,832,461(82)$ & $341,676(15)$ & $20,429(1)$ & $36,528(2)$ & $2,231,094(100)$ \\
DUN & $496,763(78)$ & $115,910(18)$ & $12,173(2)$ & $14,037(1)$ & $638,883(100)$ \\
HAM & $1,705,534(80)$ & $389,799(18)$ & $13,033(1)$ & $22,709(1)$ & $2,131,075(100)$ \\
HAWK & $489,696(81)$ & $104,253(17)$ & $5,898(1)$ & $7,605(1)$ & $607,452(100)$ \\
MANA & $1,296,871(82)$ & $261,990(17)$ & $9,338(1)$ & $15,615(1)$ & $1,583,814(100)$ \\
MARL & $222,070(75)$ & $60,677(20)$ & $6,898(2)$ & $6,341(2)$ & $295,986(100)$ \\
NELS & $437,855(75)$ & $126,516(22)$ & $8,867(2)$ & $12,356(2)$ & $585,593(100)$ \\
QUEEN & $209,307(39)$ & $193,476(36)$ & $88,501(16)$ & $49,465(9)$ & $540,750(100)$ \\
ROT & $489,976(52)$ & $364,279(39)$ & $34,328(4)$ & $46,897(5)$ & $935,480(100)$ \\
TAU & $156,820(47)$ & $160,083(48)$ & $7,706(2)$ & $10,232(3)$ & $334,841(100)$ \\
WELL & $2,345,149(73)$ & $768,353(24)$ & $37,871(1)$ & $52,145(2)$ & $3,203,518(100)$ \\
\hline
\end{tabular}

\section{References}


1. Jo, D.; Park, H.Y.; Choe, Y.; Kim, D.K. Destination-selection attributes for international association meetings: A mixed-methods study. J. Dest. Mark. Manage. 2019, 13, 61-72. https://doi.org/10.1016/j.jdmm.2019.05.005

2. Sung, H.; Lee, W. The effect of basic, performance and excitement service factors of a convention center on attendees' experiential value and satisfaction: A case study of the Phoenix Convention Center. J. Conv. Event Tour. 2015, 16, 175-199. https://doi.org/10.1080/15470148.2015.1034908

3. Becattini, G. Industrial sectors and industrial districts: Tools for industrial analysis. Eur. Plan. Stud. 2002, 10, 483-493. https://doi.org/10.1080/09654310220130194

4. Parrish, E. D.; Cassil N. L.; Oxenham, W. (2006). Niche market strategy for a mature marketplace. Mark. Intell. Plan. 2006, 24, 694-707. https://doi.org/10.1108/02634500610711860

5. Della Corte, V.; Aria, M. Coopetition and sustainable competitive advantage: The case of tourist destinations. Tour. Manag. 2016, 54, 524-540. https://doi.org/10.1016/j.tourman.2015.12.009

6. Govers, R.; Go, F.M. Deconstructing destination image in the information age, Inf. Technol. Tour, 2003, 6, 13-29.

7. Zhou, Y.; Maumbe, K.; Deng, J.; Selin, S.W. Resource-based destination competitiveness evaluation using a hybrid analytic hierarchy process (AHP): The case study of West Virginia. Tour. Manag, 2015, 15, 72-80. https://doi.org/10.1016/j.tmp.2015.03.007

8. Gomezelj, D. O.; Mihalič, T. Destination competitiveness: Applying different models, the case of Slovenia. Tour. Manag. 2008, 29, 294-307. https://doi.org/10.1016/j.tourman.2007.03.009

9. Crouch, G. I.; Del Chiappa, G.; Perdue, R. R. International convention tourism: A choice modelling experiment of host city competition. Tour. Manag. 2019, 71, 530-542. https://doi.org/10.1016/j.tourman.2018.10.002

10. Cro, S.; Martins, A. M. International association meetings: Importance of destination attributes. J. Vacat. Mark. 2018, 24, 218-233. https://doi.org/10.1177/1356766717696535

11. Dioko, L.; Whitfield, J. Price competitiveness and government incentives for simulating the meetings industry: A critical look at the case of Macau. Int. J. Event Festiv. Manag. 2015, 6, 39-53. https://doi.org/10.1108/IJEFM-07-2014-0015

12. Lee, T. J. The successful conference venue: Perceptions of conference organizers and hotel managers. Event Manag. 2009, 13, 171-180. https://doi.org/10.3727/152599509790029819

13. McCartney, G. The CAT (Casino Tourism) and the MICE (Meetings, Incentives, Conventions, Exhibitions): Key development considerations for the convention and exhibition industry in Macao. J. Conv. Event Tour. 2008, 9, 293-308. https://doi.org/10.1080/15470140802493380

14. Park, J.; Wu, B.; Shen, Y. The great halls of china? Meeting planners' perceptions of Beijing as an international convention destination. J. Conv. Event Tour. 2014, 15, 244-270. https://doi.org/10.1080/15470148.2014.961669

15. Tanford, S.; Montgomery, R.; Nelson, K. Factors that influence attendance, satisfaction, and loyalty for conventions. J. Conv. Event Tour. 2012, 13, 290-318. https://doi.org/10.1080/15470148.2012.728975

16. Hahm, J. J.; Tasci, A. D. A.; Terry, D. B. The Olympic Games' impact on South Korea's image. J. Dest. Mark. Manage. 2019, 14, https://doi.org/10.1016/j.jdmm.2019.100373

17. Mahadewi, N. M. E.; Bendesa, K. G.; Antara, I. M. Interrelation multi-factors of MICE destination to tourist revisit. Int. J. Adv. Sci. 2019, 129, 99-110.

18. van Niekerk, M. Contemporary issues in events, festivals and destination management. Int. J. Contemp. Hosp Manag. 2017, 29, 842-847. https://doi.org/10.1108/IJCHM-01-2017-0031

19 Brass, D. J.; Galaskiewicz, J.; Greve, H. R.; Tsai, W. Taking stock of networks and organizations: A multilevel perspective. Acad. Manag. J. 2004, 47, 795- 817. https://doi.org/10.5465/20159624

20 Zemla, M. Inter-destination cooperation: Forms, facilitator and inhibitors - The case of Poland. J. Dest. Mark. Manage. 2014, 3, 241-252. https://doi.org/10.1016/j.jdmm.2014.07.001

21 Lee, J.; Choi, Y.; Breiter, D. An exploratory study of convention destination competitiveness from attendees' perspective: IPA \& repeated measures of MANOVA. J. Hosp. Tour. Res. 2016, 40, 589-610. https://doi.org/10.1177/1096348013515913

22 Ordanini, A.; Pasini, P. Service co-production and value co-creation: The case for a service-oriented architecture (SOA). Eur. Manag. J. 2008, 26, 289-297. https://doi.org/10.1016/j.emj.2008.04.005

23 Kylanen, M.; Mariani, M. M. Unpacking the temporal dimension of coopetition in tourism destinations: Evidence from Finnish and Italian theme parks. Int. J. Tour. Hosp. Res. 2012, 23, 61-74. https://doi.org/10.1080/13032917.2011.653632

24 Luo, Y. Coopetition in international business. Int. Bus. Rev. 2006, 15, 436-438. https://doi.org/10.1016/j.ibusrev.2006.05.005

25 Wang, Y.; Krakover, S. Destination marketing: Competition, cooperation or coopetition. Int. J. Contemp. Hosp Manag. 2008, 20, 126-141. https://doi.org/10.1108/09596110810852122

26 Rusko, R.; Merenheimo, P.; Haanpaa, M. Coopetition, resource-based view and legend: Cases of Christmas tourism and city of Rovaniemi. Int. J. Mark. Stud. 2013, 5, 37-51.

27 Gnyawali, D. R.; Park, B. J. R. Coopetition and technological innovation in small and medium sized enterprises: A multilevel conceptual model. J. Small Bus. Manag. 2009, 47, 308-330. https://doi.org/10.1111/j.1540-627X.2009.00273.x

28 Kim, H. J.; Chen, M. H. Tourism expansion and economic development: The case of Taiwan. Tour. Manag. 2006, 27, 925-933. https://doi.org/10.1016/j.tourman.2005.05.011

29 Hong, W. C. Competitiveness in the tourism sector: A comprehensive approach from economic and management points. Physica-Verlag: Heidelberg, Germany, 2008; pp. 19-20. 
30 Harrison, B.; Foley, C.; Edwards, D.; Donaghy, G. Outcomes and challenges of an international convention center's local procurement strategy. Tour. Manag. 2019, 75, 328-339. https://doi.org/10.1016/j.tourman.2019.05.004

31 Crouch, G. I.; Ritchie, J. B. R. Convention site selection research. J. Convent. Exhibit. Manag. 1997, 1, 49-69. https://doi.org/10.1300/J143v01n01_05

32 Go, F. M.; Govers, R. The Asian perspective: Which international conference destinations in Asia are the most competitive? J. Convent. Exhibit. Manag. 1999, 1, 37-50. https://doi.org/10.1300//143v01n04 04

33 Getz, D. Bidding on events: Critical success factors. J. Convent. Exhibit. Manag. 2004, 5, 1-24. https://doi.org/10.1300/J143v05n02_01

34 Yoo, J.J.E.; Chon, K. Factors affecting convention participation decision-making: Developing a measurement scale. J. Travel Res. 2008, 47, 113-122. https://doi.org/10.1177/0047287507312421

35 Qu, H.; Li, L.; Chu, G. K. T. The comparative analysis of Hong Kong as an international conference destination in Southeast Asia. Tour. Manag. 2000, 21, 643-648.

36 Wan, Y. K. P. Assessing the strengths and weaknesses of Macao as an attractive meeting and convention destination: Perspectives of key informants. J. Conv. Event Tour. 2011, 12, 129-151. https://doi.org/10.1080/15470148.2011.565704

37 Sangpikul, A.; Kim, S. An overview and identification of barriers affecting the meeting and convention industry in Thailand. J. Conv. Event Tour. 2009, 10, 185-210. https://doi.org/10.1080/15470140903131822

38 Yoo, J.J.E. Development of the convention industry in Korea. J. Conv. Event Tour. 2004, 6, 81-94. https://doi.org/10.1300/J452v06n04_06

39 Baloglu, S.; Love, C. Association meeting planners' perceptions and intentions for five major US convention cities: The structured and unstructured images. Tour. Manag. 2005, 26, 743-752. https://doi.org/10.1016/j.tourman.2004.04.001

40 Nadkarni, S.; Leong, A. M. W. Macao's MICE dreams: Opportunities and challenges. Int. J. Event Manag. Res. 2007, 3, 47-57.

41 Akerman, A.; Py, L. (Stockholm University, Stockholm, Sweden). Service Outsourcing and Specialization: A Theory on Endogenous Task Scope (2010).

42 Dimmick, J.; Kline, S.; Stafford, L. The gratification niches of personal e-mail and the telephone: Competition, displacement, and complementarity. Commun. Res. 2000, 27, 227-248. https://doi.org/10.1177/009365000027002005

43 Min, S. J.; Kim, Y. M. Choosing the right media for mobilization: Issue advocacy groups' media niches in the competitive media environment. Mass. Commun. Soc. 2012, 15, 225-244. https://doi.org/10.1080/15205436.2011.568316

44 Gan, C.; Wang, W. Uses and gratifications of social media: A comparison of microblog and WeChat. J. Inf. Technol. 2015, 17, 351-363. https://doi.org/10.1108/JSIT-06-2015-0052

45 Dimmick, J. W.; Patterson, S. J.; Albarran, A. B. Competition between the cable and broadcast industries: A niche analysis. J. Media Econ. 1992, 5, 13-30. https://doi.org/10.1080/08997769209358215

46 Nelson, R. R.; Winter, S. G. An Evolutionary Theory of Economic Change. Harvard University Press: Cambridge, MA, UK, 1982; pp. 348-351.

47 McPherson, M. An ecology of affiliation. Am. Sociol. Rev. 1983, 48, 519-532. https://doi.org/10.2307/2117719

48 Kim, C.; Park, H. S. Competition or coexistence? Public relations industry in Korea: An application of the theory of the niche. Korea. J. Public Relat. 2006, 10, 126-160.

49 Dimmick, J. Media competition and coexistence: The theory of the niche, $1^{\text {st }}$ ed; Lawrence Erlbaum: Mahwah, NJ. USA, 2003; pp. 118-129.

50 Dimmick, J.; Feaster, J. C.; Ramirez Jr., A. The niche of interpersonal media: Relationships in time and space. New Media Soc., 2011, 13, 1265-1282. https://doi.org/10.1177/1461444811403445

51 Haniff, Z. Niche theory in new media: Is digital overtaking the print magazine industry? Master degree thesis, University of Nevada, Las Vegas. USA, 5-1-2012.

52 Ramirez Jr., A.; Dimmick, J.; Feaster, J.; Lin, S. F. Revisiting interpersonal media competition: The gratification niches of instant messaging, e-mail, and the telephone. Commun. Res. 2008, 35, 529-547. https://doi.org/10.1177/0093650208315979

53 Ford, R. C.; Peeper, W. C. Managing destination marketing organization. ForPer Publications: Orlando, FL, USA, 2008 ; pp. 548.

54 Bengtsson, M.; Kock, S. "Coopetition” in business networks: To cooperate and compete simultaneously. Ind. Mark. Manag. 2000, 29, 411-426. https://doi.org/10.1016/S0019-8501(99)00067-X

55 Bouncken, R. B.; Gast, J.; Kraus, S.; Bogers, M. Coopetition: A systematic review, synthesis, and future research directions. Rev. Manag. Sci. 2015, 9, 577-601. https://doi.org/10.1007/s11846-015-0168-6

56 Bengtsson, M.; Raza-Ullah, T.; Vanyushyn, V. The coopetition paradox and tension: The moderating role of coopetition capability. Ind. Mark. Manag. 2016, 53, 19-30. https://doi.org/10.1016/j.indmarman.2015.11.008

57 Ritala, P.; Hurmelinna-Laukkanen, P. What's in it for me? Creating and appropriating value in innovation-related coopetition. Technovation, 2009, 29, 819-828. https://doi.org/10.1016/j.technovation.2009.07.002

58 Bengtsson, M.; Kock, S. Coopetition - quo vadis? Past accomplishments and future challenges. Ind. Mark. Manag. 2014, 43, 180-188. https://doi.org/10.1016/j.indmarman.2014.02.015

59 Dimmick, J.; Chen, Y.; Li, Z. Competition between the internet and traditional news media: The gratification-opportunities niche dimension. J. Media Econ. 2004, 17, 19-33. https://doi.org/10.1207/s15327736me1701_2

60 Cho, Y. (Korean Institute of Intellectual Property, Seoul, Korea; Lee, Y. (Korean Institute of Intellectual Property, Seoul, Korea). Technology Strategy under Industrial Environment of 'coopetition': Patent Analysis in Mobile Industry, 2014. 
61 Becattini, G. Industrial sectors and industrial districts: Tools for industrial analysis. Eur. Plan. Stud. 2002, 10, 483-493. https://doi.org/10.1080/09654310220130194

62 Getz, D.; Andersson, T. Analyzing whole populations of festivals and events: An application of organizational ecology. J. Policy Res. Tour. Leis. Events, 2016, 8, 249-273. https://doi.org/10.1080/19407963.2016.1158522 